\title{
Sensitivity of firm size measures to practices of corporate finance: evidence from BRICS
}

\author{
Syed Danial Hashmi*, Saqib Gulzar ${ }^{2}$, Zeshan Ghafoor ${ }^{1}$ and Iram Naz
}

\begin{abstract}
Firm size has remained a major area of investigation for researchers from a long time. This study aims at examining impact of different measures of firm size (total assets, total sales, market capitalization and number of employees) on seven important practices of corporate finance which are financial policy, dividend policy, investment policy, diversification, firm performance, compensation and incentives and board structure (corporate governance). Moreover, this study also examines the sensitivity of different proxies of firm size on these practices of corporate finance. Data from BRICS (Brazil, Russia, India, China and South Africa) have been analysed. Overall results supported the hypotheses. Study concludes that different proxies of firm size are differently related to practices of corporate finance based on sign, significance and $R^{2}$. All proxies capture different aspects of firm size and have different implications for corporate finance. Thus, this study confirms "measurement effect" in "size effect". Unfortunately, this means that many of past studies may not be robust and are biased. Researchers thus need to be careful when selecting any proxy of firm size for their research keeping in mind the scope and context of their work. Choosing a proxy thus is a theoretical and empirical question.
\end{abstract}

Keywords: Firm size, Size effect, Practices of corporate finance, Sensitivity, BRICS

\section{Introduction}

Firm size has remained a major area of investigation in corporate finance. Coase [1] is credited for the seminal work in this area. He raised questions on what determines firm boundaries and how these boundaries affect allocation of resources. What determines firm size has remained a major question under investigation by the researchers. Different theories of firm explain the reasons behind the existence of a firm [2]. You [3] surveyed diverse literature on the theories of firm size (determinants and distribution) and classified the literature into four streams including technological approach or the conventional microeconomics approach, institutional approach commonly known as transactional economics approach, industrial organizational (IO economics) approach and dynamic modelling approach.

\footnotetext{
*Correspondence: danial.hashmi@riphah.edu.pk

${ }^{1}$ Faculty of Management Sciences, Riphah International University,

Rawalpindi, Islamabad, Pakistan

Full list of author information is available at the end of the article
}

Researchers have examined the impact of organizational/firm size on different kinds of outcomes in different fields of organizational management including but not limited to executive compensation [4-6], innovation [7-11], organizational change [12], functional complexity [13], hiring practices and job search behaviour [14], unemployment [15], managerial succession [16], buying influences [17], job shift patterns [18], individual's ethical predispositions [19] and corporate social responsibility $[20,21]$. Researchers in finance have also tried to examine the relationship between firm size and different variables. Firm size has been studied in relation to capital structure [22, 23], financial policy [24], dividend policy [24-27], leverage [28] and merger and acquisition [29].

Although these empirical studies in corporate finance agree that firm size matters, no study till date has comprehensively examined effect of different measures or proxies of firm size on important practices of corporate finance. Only such study known to the researcher is of Dang et al. [30] who investigated the impact of firm size on eight practices of empirical corporate finance which 
were financial performance, financial policy, corporate governance, dividend policy, compensation policy, investment policy, diversification and lastly mergers, acquisition and corporate control. They used data from Latin America and called for future research on the issue. Recently, Hashmi et al. [31] have also conducted research on the same issue using data from Sharı 'ah compliant firms. Obviously, for a discipline to be regarded as scientific there shall be sufficient evidence for a construct to become a well-established theory. Further, researchers argued that no study in finance using firm size as a variable has provided any justification for the use of any proxy/measure employed in that research. This means that until now researchers have decided by their own will about selection of firm size measure without providing any logic.

This point carries serious repercussions. It must be noted that all measures of firm size are theoretically different and capture different aspects of size. A researcher might use a proxy/measure while examining firm size in relation to any area of corporate finance which might be irrelevant or has no connection to that specific area. Previous researchers have noted this problem, e.g. while examining leverage in relation to size, Ebel Ezeoha [24] argued that mixed results of past researchers on relationship between size and leverage does not mean that size simultaneously is positively and negatively related to leverage neither does it mean that all these findings are contextually wrong nor that size and leverage are uncorrelated. He noted that it is the difference in definitions of firm size employed by all the papers (employing different measures/proxies) which resulted in different results. Thus, examining sensitivity of different proxies of firm size in relation to practices of corporate finance is essential.

Therefore, this study examines the impact of different measures of firm size, namely total assets, total sales, market capitalization and total number of employees on seven important areas/practices of corporate finance including financial policy, investment policy, dividend policy, diversification, managerial compensation and incentives, firm performance and corporate governance. Specifically, study checks for $R^{2}$ sensitivity, beta coefficient sensitivity and significance level sensitivity of all four different measures of firm size with these seven areas. Further, this study uses data from five emerging economies, i.e. Brazil, Russia, India, China and South Africa (BRICS). Our study adds to the existing body of knowledge in several ways: we have examined the effect of different measures of firm size on different corporate finance policies or simply corporate choices comprehensively. Our study is replication and extension of Dang et al. [30] who examined the same. However, we used different data sets and different years. We also included another measure of firm size, i.e. number of employees. We have used data from economic block of five emerging economies, i.e. BRICS. Overall, our results supported the formulated hypotheses. Different proxies of firm size have been found to differently relate to all areas/practices of corporate finance based on beta coefficient value, $R^{2}$ and sign of coefficient.

\section{Theory and hypotheses}

\section{Firm size and financial policy}

Financial policy of a firm describes a firm's decision regarding debt-equity mix (capital structure, leverage), maturity structure, cash holdings and method of financing and hedging decisions. From theoretical perspective, large firms will be more levered then small firms. As large firms have more investment opportunities to grow, Ebel Ezeohai [24] argued that this means large firms would be able to get more financing because of its growth. Taking it from another perspective, banks are always more willing to give debt to those customers whether individual or institutional who have more creditworthiness. Large firms because of their reputation in society would thus appeal more suitable to be given loan than small firms.

Previous research has shown mixed results with some researchers reporting positive relationship between the two, i.e. firm size and leverage [24, 28, 31-37], while some other reporting negative relationship between two $[38,39]$. However, the first school of thought appears to be dominating in the literature. Further, as previously mentioned Ebel Ezeoha [24] in his study mentioned that these mixed results do not mean that size simultaneously is positively and negatively related to leverage neither does it mean that all these findings are contextually wrong nor that size and leverage are totally not correlated. According to Ebel Ezeoha [24], it is the difference in definitions of firm size employed by all of the papers. It must be taken in notice that this study employed four best possible measures of firm size to check the impact on leverage; it is thus expected that results of this study will provide direction as to which measures can yield positive and which can yield negative relationship with leverage. Based on all the above discussion, this study hypothesizes that:

H1 Firm size has a significant impact on financial policy 


\section{Firm size and dividend payout policy}

Dividend policy explains that whether a firm pays out dividend to investors or retains its earnings for future investments. According to theoretical perspective, small firms focus more on growth and this factor causes them to pay fewer dividends and retains their earnings for future expansion of business. Conversely, large firms are more stable and give dividend to the investor to gain trust of them.

Taking it from the perspective of signalling theory, large firms issue dividend to give a "good" signal to the market that the firm is earning much and is financially stable and in good position. Alternatively, not issuing dividend will be considered as "bad" sign by the market because market might feel that the firm has not enough money and is not financially viable causing market price of the shares of large firm to decline.

Agency theory of Jensen and Meckling [40] provides another explanation of this phenomenon. Agency theory argues that investors perceive dividend as a shield of their investments as they feel that dividend will reduce the cash available to managers which can be used against the will of shareholders. Previous research has shown that the more a firm expands, grows and tries to cross national boundaries (become large), the more agency cost it has to face (e.g. see [41]). This means that investors of large firms want dividend and that large firms will issue dividend to satisfy its investors and reduce the agency cost. Empirical evidence also supports link between firm size and dividend policy [25-27, 42-44]. It is thus hypothesized that:

H2 Firm size has a significant impact on dividend policy

\section{Firm size and investment policy}

Investment policy refers to the investment decision of a firm which means the capital expenditure a firm is willing to make. Large companies must deal with larger projects, while dealing with large projects they can easily make cost of sophisticated investment appraisal techniques look small. This means that large companies would have a significant investment policy being shown by large NPVs and other appraisal techniques. Empirical evidence suggests a relationship between firm size and investment policy. (e.g. see [30, 45-48]). Similarly, large firms have more access to financing and have more internal resources thus which makes large firms able to make more capital expenditure as compared to small firms [31].
H3 Firm size has a significant impact on investment policy

\section{Firm size and diversification}

Diversification is widely studied in managerial research. Researchers in strategic management, industrial organization and financial management have long been studying diversification and its impact on different organizational outcomes [49].

Firm size plays a vital role in determination of business diversification of a firm. Business diversification is not cost free, and it requires financing. It is previously well established in this study that large firms can get financing from banks (because of their repute) and from stock market (by issuing shares for new business segments) more conveniently than small firms. This means that large firms can easily diversify their businesses as compared to small firms.

Small firms might have expertise in one production and operational area in which that firm is operating. On the other hand, because of vast business operations and huge links with the industry (both related and unrelated), large firms have the advantage of know-how of the operations of other firms operating in industry. Diversification needs minds from other business sectors, minds which know how work is done in that industry and minds that can yield profit for the firm. These minds are certainly the experts of those industries in which a company is going to operate. Cost of hiring those experts is also flying high, and it is well established that large firms give huge managerial compensations and incentives. So, it will be easier for a large firm as compared to small firm to hire those experts.

Growing by diversifying is not the only option for growth. In fact, small firms will tend to grow by using concentration strategy, i.e. by gaining superiority in the product it is manufacturing or the market it is operating in. On the other hand, most of the large firms would already have concentrated in their industry and will thus go for diversifying its product and business portfolio.

Previously, certain studies have examined this relationship in mergers and acquisitions (e.g. see [50]). Using event analysis technique and examining 44 mergers and acquisitions, they found that diversification is related to the firm size when it comes to M\&A's. Dang et al. [30] examined firm size in relation to business diversification. Their results for both business segments and Herfindahl index were robust. They concluded that large firms are more diversified than small firms. Based on the above discussion, this study hypothesizes that:

H4 Firm size has a significant impact on diversification 


\section{Firm size and firm performance}

According to Deshpande et al. [51], organizational performance has different aspects, such as relationship-building performance, short-term and long-term performance, financial and non-financial performance. Firm performance in finance strictly refers to financial performance, i.e. return on investments made by the firm and its shareholders in firm itself. It excludes all other types of performance specifically social performance of the firm. Theoretically speaking, the larger the firm is, the larger its operations will be, and the more it will produce resulting in more sales. Higher sales will lead to higher revenue and higher revenue means high profit; high profit will ultimately mean high income, and the more the income or profit after taxes, the more will be the return on investments/assets and return on equity.

From another perspective, large firms can generate investor's trust more than small firms. This means that investor will trust the company and this trust would be shown in equity market by the investor. High trust of investor means high investment by the investor in the market, and high investment by the investor would ultimately raise the market value of equity (ignoring the fact that it might get overvalued). A high value of equity is another strong financial indicator.

Empirical evidence also suggests a relationship between firm size and performance/profitability (e.g. see, [30, 31, $52,53])$. Keeping in view the above discussion, this study hypothesizes that:

H5 Firm size has a significant impact on firm performance

\section{Firm size and managerial compensation and incentives}

Managerial compensation and incentives refer to the salary and other benefits which top executive of any company receive. Although managerial compensation or compensation in particularly is not a new topic at all and is existing since the existence of mankind or at least from the existence of "labour market", however, it was only in late 80 s and early 90 s when the area of managerial compensation started emerging in managerial research.

Researchers in strategic management have been credited for making existence of this body of knowledge possible; by using the area of financial economics, they have studied the influence of top executives on organization [54]. Agency theory [40] has provided a framework of how firms can minimize the conflict of interest between principle, i.e. shareholders, and agent, i.e. managers. A stream of researchers studying agency theory have thus studied managerial compensation and incentives as a prospect to minimize the agency cost or what is commonly known as conflict of interest between management and shareholders. Fama [60] noted that agency literature on executive compensation has emphasized incentives and risk-bearing issues.

Graham et al. [55] in their study examined unobservable firm and managerial characteristics, e.g. latent management skills on compensation. They decomposed the variation in executive compensation and found that timeinvariant firm and managers fixed effects explain most of the variation in executive pay. When it comes to observable firm characteristics like firm size, [55] noted that the relation between firm size and compensation of executives is well documented in the literature.

Taking it from the perspective of RBV [56], i.e. resource-based view of firm, RBV assumes top management as a unique pool of resources that are valuable, rare, imperfectly imitable and non-substitutable (VRIN), and thus, this top executive human resource is one which is the source of competitive advantage of firm. So, in order to remain competitive a firm needs to keep its top management intact as minds once gone cannot be replaced. Large firms will thus enhance and increase the compensation and benefits of their top management so that they do not leave that firm. From perspective of agency theory, as previously mentioned large firms and especially multinationals are more prone to agency cost and agency conflict. This means large firms will do more measures to reduce agency cost and conflict. One prospective way as presented by Jensen and Meckling [40] themselves to reduce conflict and cost was to increase management incentives and give them stock options. Thus, large firms according to agency perspective will be able to pay more and give more incentives to the managers as compared to small firms. Small firms on the other hand are mostly family owned and cannot afford to lose or change shareholding pattern, so they will hesitate more in giving stock options to employees.

Empirical evidence supports this notion. This is well established in the literature that firm size has an impact on executive compensation and incentives [30, 55, 57]. It is thus hypothesized that:

H6 Firm size has a significant impact on compensation and incentives

\section{Firm size and corporate governance mechanism (board structure)}

Corporate scandals and corporate failures of recent times including but not limited to Enron, Tyco, WorldCom, etc., swung the whole world, and researchers and practitioners deemed it necessary to have governance mechanisms resulting in a full-fledged area in managerial 
sciences, i.e. corporate governance. Litch [58] defined governance as rules and structures for wielding power over interest of people including use and abuse of power.

Daily et al. [59] summarized the decades of dialogues and data on corporate governance. According to them, three theories are base of the governance mechanisms: agency theory of Jensen and Meckling [40], resource dependence theory and stewardship theory. All of these three have different implications for governance in organizations.

One of the most important areas in governance is board of directors. By definition, board of directors is elected by shareholders in company's annual general meeting. It has been argued from a long time that effective board structure would consist of outside independent directors (e.g. see [60]) and the debate got more importance after the corporate scandals. Advocates of corporate governance argue that there shall be more non-executive directors and in fact more independent directors who shall be outsiders to the company in order to ensure the efficiency of board. Theoretically, with increase in size of firm, owners of firm, i.e. shareholders, will increase. Increase in shareholders would mean an increase in size of board in order to make board more representative. Dang et al. [30] found support of this argument too. They reported a positive $R^{2}$ for the relationship between firm size and board size.

In a same way, large firms have more regulations to follow as they are mostly public and have to follow the regulations of the regulatory authorities. Regulatory authorities in most of the world nowadays demand more outside and especially independent directors. It is thus believed that large firms will tend to have more independent directors than small firms. Dang et al. [30] found empirical support for such an argument. Dang et al. [30] however used board independence, board size and CEO duality to check impact of size on board dynamics. This study adopted board independence as it is most important for governance mechanism. Keeping in view the above discussion, this study proposes that:

H7 Firm size has a significant impact on board structure.

\section{Sensitivity of firm size measures}

It is evident up till now that firm size has remained a major area of investigation in finance and a lot of researchers not only in finance but also in other managerial sciences believe that firm size does really matter. However, no research till now has provided any reason for using a specific measure of firm size for a specific variable [30]. This is a reason that different measures of firm size have yielded different results and results of many variables with firm size appeared mix [31].

Researchers have noted this problem. As mentioned earlier, Ebel Ezeoha [24] noted that the mixed results on size-leverage relationship in past do not mean that size simultaneously is positively and negatively related to leverage neither does it mean that all these findings are contextually wrong nor that size and leverage are totally not correlated. According to Ebel Ezeoha [24], it is the difference in definitions of firm size employed by all of the papers which is the primary cause of this scenario. Dang et al. [30] also noted that overall assessment of firm size measures in corporate finance is missing. It is thus believed that different measures of firm size, i.e. total assets, total sales and market value of equity, will be differently related to different variables of corporate finance. Thus, this study hypothesizes that:

H8 Different measures of firm size would have different sensitivities regarding different practices of corporate finance

\section{Methods \\ Data}

This study used data from BRICS, i.e. Brazil, Russia, India, China and South Africa. BRICS includes nations with high growth potential, and all are emerging economies. Together, BRICS covers more than $40 \%$ of world's population, contributes about 15\% of global GDP and has more than $30 \%$ of world reserves [61]. All of the five economies are leading emerging economies and have been seen as a shift in global economic power away from developed economies [62]. It is thus prudent to look at these emerging markets to examine sensitivity of firm size measures to practices of corporate finance.

For analysis purpose, BRICS was treated as one block rather than separate countries. In line with the convention of standard finance, this study also used data from non-financial sector and excluded any financial firm. Data of 25 companies from each country over a period of 10 years, i.e. 2006-2015, were collected. Selection of companies was based on capitalization. For measures of firm size, data were collected from annual reports of companies, and board structure's data were collected from company's filings to SEC of that respective country; data on fundamentals of firm were collected from either website of that firm, annual reports or independent websites.

In case of pay level, unavailability of data forced researcher to set different levels based upon which it was decided that whether company will be given a 0 (i.e. no pay levels disclosed) or 1 (i.e. pay levels disclosed). The 
decision was made on the fact that which company has better disclosures. It must be kept in mind that it is mandatory requirement of SEC throughout the world that companies should disclose the compensation and benefits given to board of directors and three main officers of the company. This was thus settled as the base requirement. For a company to get a 1 and be considered as disclosing information regarding pay level, researcher checked that whether that specific company go beyond these criteria and disclosed much or some information regarding things mentioned as follows:

- Disclosure regarding salary of different managerial cadres

- Disclosure regarding stock compensation

- Disclosure regarding any salary and compensation of other major officers of the company.

If any company had disclosed any significant information about these points, it was given 1 or else 0 .

\section{Measures}

Measures employed in study are summarized in form of table (Table 1)

\section{Control variables}

Control variables for each model have been identified based upon the benchmark papers of that area and those as used by Dang et al. [30]. The study has not used all the controls as identified in the benchmark papers which could have caused an unmanageable scope of the study. The benchmark paper for firm performance was of Mehran [63]; for board structure, it was of Linck et al. [64];
Frank and Goyal [65] for leverage; and Coles et al. [66] for investment policy and diversification. Our selection of control variables is also in line with those of Dang et al. [30] and Hashmi et al. [31].

\section{Results}

\section{Correlation analysis}

Table 2 shows descriptive statistics and correlation analysis for the study. The total number of observations of the study was 1250 . It can be seen in the table that different proxies of firm size are differently related to corporate choices. Firm size as measured by total assets is significantly correlated with financial leverage (assets/ equity) $(r=0.11, p<0.05)$, financial leverage (debt/equity) $(r=0.17, p<0.05)$, business segments, i.e. diversification $(r=0.20, p<0.05)$, dividend policy $(r=0.18, p<0.05)$, CAPEX, i.e. investment policy $(r=0.16, p<0.05)$, independent directors $(r=0.20, \quad p<0.05)$, non-executive directors $(r=0.23, p<0.05)$, pay level $(r=0.18, p<0.05)$, ROA $(r=0.19, p<0.05)$ and $\operatorname{ROE}(r=0.06, p<0.10)$. Similarly, it can be seen that size as measured by total sales is significantly correlated with financial leverage (assets/ equity) $(r=0.19, p<0.05)$, financial leverage (debt/equity) $(r=0.16, p<0.05)$, business segments, i.e. diversification $(r=0.19, p<0.05)$, dividend policy $(r=0.25, p<0.05)$, CAPEX, i.e. investment policy $(r=0.34, p<0.05)$, independent directors $(r=0.23, \quad p<0.05)$, non-executive directors $(r=0.18, p<0.05)$, pay level $(r=0.20, p<0.05)$, ROA $(r=0.13, p<0.05)$ and $\operatorname{ROE}(r=0.17, p<0.05)$. It can also be seen that size as measured by market value of equity is significantly correlated with financial leverage (assets/equity) $(r=-0.08, \quad p<0.05)$, financial leverage (debt/equity) $(r=-0.06, p<0.10)$, business

Table 1 Measures employed in the study

\begin{tabular}{|c|c|c|c|}
\hline Variable & Nature of variable & Proxy & Measure \\
\hline \multirow[t]{4}{*}{ Firm size } & Independent variable & Total assets & Ln (total assets) \\
\hline & & Total sales & Ln (total sales) \\
\hline & & Market value of equity & Ln (market cap) \\
\hline & & Number of employees & Ln (number of employees) \\
\hline \multirow[t]{2}{*}{ Financial policy } & Dependent variable & Financial leverage & Book value of debt/equity \\
\hline & & Financial leverage & Total asset/total equity \\
\hline Payout policy & Dependent variable (dummy) & Dividend payout & Dividend payment (dummy) \\
\hline Investment policy & Dependent variable & CAPEX & Net CAPEX/total asset \\
\hline Diversification & Dependent variable & Business segments & Ln (no. of business segments) \\
\hline \multirow[t]{2}{*}{ Firm performance } & Dependent variable & $\mathrm{ROA}$ & Profit after taxes/total asset \\
\hline & & $\mathrm{ROE}$ & PAT/total equity \\
\hline Managerial compensation and incentives & Dependent variable & Pay level & Pay level and disclosers (dummy) \\
\hline \multirow[t]{2}{*}{ Corporate governance (board structure) } & Dependent variable & Board independence & Ln (no. of independent directors on board) \\
\hline & & & Ln (no. of non-executive directors on board) \\
\hline
\end{tabular}


Table 2 Descriptive statistics and correlation

\begin{tabular}{|c|c|c|c|c|c|c|c|c|c|c|c|c|c|c|c|c|}
\hline & Mean & SD & 1 & 2 & 3 & 4 & 5 & 6 & 7 & 8 & 9 & 10 & 11 & 12 & 13 & 14 \\
\hline 1. FL (assets to equity) & 0.04 & 0.08 & 1.00 & & & & & & & & & & & & & \\
\hline 2. FL (debt to equity) & 0.76 & 0.63 & $0.31^{*}$ & 1.00 & & & & & & & & & & & & \\
\hline 3. Business segment & 0.70 & 1.20 & -0.07 & -0.03 & 1.00 & & & & & & & & & & & \\
\hline 4. Dividend policy & 0.75 & 0.69 & $-0.11^{*}$ & -0.07 & $-0.07^{*}$ & 1.00 & & & & & & & & & & \\
\hline 5. CAPEX & 0.85 & 0.36 & -0.02 & -0.03 & $0.12^{*}$ & 0.05 & 1.00 & & & & & & & & & \\
\hline 6. Independent directors & 1.37 & 0.60 & $-0.06^{*}$ & $-0.11^{*}$ & $0.26^{*}$ & $0.25^{*}$ & $0.07^{*}$ & 1.00 & & & & & & & & \\
\hline 7. Non-executive director & 0.57 & 0.56 & $-0.11^{*}$ & $-0.02^{*}$ & $0.16^{*}$ & $0.18^{*}$ & $0.06^{*}$ & $0.52^{*}$ & 1.00 & & & & & & & \\
\hline 8. Pay level & 0.68 & 0.47 & -0.03 & $-0.03^{*}$ & $0.19^{*}$ & $0.08^{*}$ & $0.06^{*}$ & $0.24^{*}$ & $0.06^{*}$ & 1.00 & & & & & & \\
\hline 9. $\mathrm{ROA}$ & 8.83 & 4.77 & $-0.13^{*}$ & $-0.19 *$ & $0.18^{*}$ & $0.09^{*}$ & $0.19^{*}$ & -0.01 & 0.03 & $0.59^{*}$ & 1.00 & & & & & \\
\hline 10. ROE & 8.02 & 4.26 & $-0.13^{*}$ & $-0.15^{*}$ & $0.09^{*}$ & $0.06^{*}$ & $0.11^{*}$ & 0.01 & $0.08^{*}$ & 0.03 & $0.56^{*}$ & 1.00 & & & & \\
\hline 11. Size: Ln (MVE) & 12.43 & 2.72 & $-0.08^{*}$ & $-0.06^{*}$ & $0.21^{*}$ & $0.23^{*}$ & $0.05^{*}$ & $0.46^{*}$ & $0.14^{*}$ & $0.27^{*}$ & $0.33^{*}$ & $0.16^{*}$ & 1.00 & & & \\
\hline 12. Size: Ln (total asset) & 11.18 & 1.90 & $0.11^{*}$ & $0.17^{*}$ & $0.20^{*}$ & $-0.18^{*}$ & $0.16^{*}$ & $0.20^{*}$ & $0.23^{*}$ & $0.18^{*}$ & $0.19^{*}$ & 0.06 & $0.37^{*}$ & 1.00 & & \\
\hline 13. Size: Ln (total sale) & 10.60 & 2.12 & $0.19^{*}$ & $0.16^{*}$ & $0.19^{*}$ & $0.25^{*}$ & $0.34^{*}$ & $0.23^{*}$ & $0.18^{*}$ & $0.20^{*}$ & $0.13^{*}$ & $0.17^{*}$ & $0.43^{*}$ & $0.83^{*}$ & 1.00 & \\
\hline 14. Size: \# of employees & 9.82 & 1.83 & $-0.05^{*}$ & -0.04 & $0.24^{*}$ & $0.28^{*}$ & $0.14^{*}$ & $0.13^{*}$ & $0.19^{*}$ & $0.24^{*}$ & 0.01 & $0.13^{*}$ & $0.34^{*}$ & $0.41^{*}$ & $0.47^{*}$ & 1.00 \\
\hline
\end{tabular}

$F L$ financial leverage, $S D$ standard deviation

${ }^{*} p<0.10, n=1250$

segments, i.e. diversification $(r=0.21, p<0.05)$, dividend policy $(r=0.23, p<0.05)$, CAPEX, i.e. investment policy $(r=0.05, p<0.05)$, independent directors $(r=0.46$, $p<0.05)$, non-executive directors $(r=0.14, p<0.05)$, pay level $(r=0.27, p<0.05)$, ROA $(r=0.33, p<0.05)$ and ROE $(r=0.16, p<0.10)$. Likewise, size as measured by total number of employees is significantly correlated with financial leverage (assets/equity) $(r=-0.05, p<0.10)$, business segments, i.e. diversification $(r=0.24, p<0.05)$, dividend policy $(r=0.28, p<0.05)$, CAPEX, i.e. investment policy $(r=0.14, p<0.05)$, independent directors $(r=0.13, \quad p<0.05)$, non-executive directors $(r=0.19$, $p<0.05)$, pay level $(r=0.24, p<0.05)$ and $\operatorname{ROE}(r=0.13$, $p<0.10)$. However, size as measured with total number of employees has no relation with financial leverage (debt/ equity) $(r=-0.04, \mathrm{~ns})$ and ROA $(r=0.01, \mathrm{~ns})$.

\section{Regression analysis \\ Firm size and financial policy}

Table 3 shows the results of pooled OLS regression for firm size and financial leverage. ROA is the control variables. It can be seen in the table that all proxies of firm size are significantly related to financial leverage of firm: total assets-financial leverage $(\beta=-0.03, p<0.01)$, total sales-financial leverage $(\beta=-0.21, p<0.01)$, MVEfinancial leverage $(\beta=-0.37, p<0.01)$ and number of employees and financial leverage $(\beta=-0.003, p<0.01)$. Value of $R^{2}$ for all these four models was 0.03, 0.17, 0.05 and 0.02, respectively. Before estimation of fixed effect regression, Hausman test was done to see whether fixed effect model is appropriate or random is appropriate.
Results of Hausman test for financial policy are shown in Table 4.

In the table, it can be seen that for financial leverage (assets to equity), fixed effect regression is appropriate in all relationships except in case of total assets. Result of fixed/random effect regression as shown in the table shows that all proxies of firm size are significantly yet differently related to financial leverage: total assets-financial leverage $(\beta=0.05, p<0.1)$, total salesfinancial leverage $(\beta=-0.07, p<0.01)$, MVE-financial leverage $(\beta=-0.19, p<0.05)$ and number of employees and financial leverage $(\beta=-0.01, p<0.01)$. The value of $R^{2}$ for these relationships was $0.07,0.07,0.07$ and 0.20 , respectively.

In case of debt-equity as DV, pooled OLS regression as shown in Table 5 shows that firm size as measured by total assets is significantly related to debt-equity $(\beta=0.07, p<0.01)$, total sales are also significantly related to debt-equity $(\beta=0.08, p<0.01)$, MVE is significantly related to debt-equity $(\beta=0.03, p<0.01)$ and number of employees and debt-equity relationship is also significant $(\beta=0.03, p<0.01)$. The value of $R^{2}$ for these relationships was $0.04,0.04,0.03$ and 0.09 , respectively. Results of Hausman test as shown in Table 4 show that random effect regression is appropriate in case of number of employees-debt/equity relationship, and fixed effect is appropriate otherwise.

Results of fixed/random effect are also mentioned in Table 5. The table shows that there exists insignificant relationship between firm size as measured by number of employees and debt-equity $(\beta=0.02$, ns). However, relationship between firm size as measured by total 
Table 3 Regression analysis of firm size (total asset, total sales, MVE and number of employees) and financial leverage

\begin{tabular}{|c|c|c|c|c|c|c|c|c|}
\hline & $(1)$ & $(2)$ & (3) & $(4)$ & (5) & (6) & $(7)$ & (8) \\
\hline & Pooled OLS & Pooled OLS & Pooled OLS & Pooled OLS & RE & FE & FE & FE \\
\hline C & $-3.50^{* * *}$ & $-3.78^{* * *}$ & $-3.17^{* * *}$ & $0.08^{* * *}$ & $-3.76^{* * *}$ & $-3.79^{* * *}$ & $-3.49^{* * *}$ & $0.21^{* * *}$ \\
\hline $\mathrm{ROA}$ & $-0.05^{* * *}$ & $-0.18^{* * *}$ & $-0.11^{* * *}$ & $0.004^{* * *}$ & $0.01^{\mathrm{ns}}$ & $0.01^{\mathrm{ns}}$ & $0.01^{\mathrm{ns}}$ & $-0.001^{\mathrm{ns}}$ \\
\hline Size: Ln(assets) & $-0.03^{* * *}$ & & & & $0.05^{*}$ & & & \\
\hline Size: Ln(sales) & & $-0.21^{* * *}$ & & & & $-0.07^{* * *}$ & & \\
\hline Size: Ln(MVE) & & & $-0.37^{* * *}$ & & & & $-0.19^{* *}$ & \\
\hline Size: number of employees & & & & $-0.003^{* * *}$ & & & & $-0.01^{* * *}$ \\
\hline Year fixed effect & Yes & Yes & Yes & Yes & Yes & Yes & Yes & Yes \\
\hline$R^{2}$ & 0.03 & 0.17 & 0.05 & 0.02 & 0.07 & 0.07 & 0.07 & 0.20 \\
\hline \#Observations & 1250 & 1250 & 1250 & 1250 & 1250 & 1250 & 1250 & 1250 \\
\hline \multicolumn{9}{|l|}{$F$ test } \\
\hline \multicolumn{9}{|l|}{ Chi2(3) $=9.25$} \\
\hline \multicolumn{9}{|c|}{$p$ value $=0.026$} \\
\hline \multicolumn{9}{|c|}{ Explanatory Variable: Leverage (TA/TE) } \\
\hline \multicolumn{9}{|c|}{ Models (1)-(4) represent simple pooled OLS results i.e. Common effect } \\
\hline \multicolumn{9}{|c|}{ Model (5)-(8) represent Fixed/Random effect regression based on results of Hausman test stated above } \\
\hline$* * *, * *,{ }^{*}$ represent $1 \%, 5 \%$ and & $\%$ level of signific & ce respectively, & represents not s & ificant & & & & \\
\hline
\end{tabular}

assets and debt-equity is significant $(\beta=0.21, p<0.01)$, firm size as measured by MVE and debt-equity is significant $(\beta=0.06, p<0.01)$ and firm size as measured by total sales and debt-equity is significant $(\beta=0.11$, $p<0.01)$. The value of $R^{2}$ for model 5 , i.e. total assetsfinancial leverage (debt to equity), is 0.04 , for model 6 , i.e. total sales-financial leverage (debt to equity), it is 0.05 , for model 7 , i.e. MVE-financial leverage (debt to equity), is 0.02 and for model 8 , i.e. number of employees-financial leverage (debt to equity), is 0.12 . These results thus support hypothesis $\mathrm{H} 1$.

\section{Firm size and investment policy}

Table 6 shows results for pooled OLS of firm size measures on CAPEX as scaled by total assets. Stock return and leverage are the control variables. Results as shown in the table indicate that all proxies of firm size are significantly negatively related to CAPEX, i.e. total assets $(\beta=-0.08, p<0.01)$, sales $(\beta=-0.09, p<0.01)$, MVE $(\beta=-0.08, p<0.01)$ and number of employees $(\beta=-0.09, p<0.01)$. Value of $R^{2}$ for all these four models was $0.18,0.19,0.17$ and 0.14 , respectively. Results of fixed effect regression show that relationship of number of employee-CAPEX is insignificant $(\beta=0.002$, $\mathrm{ns})$, total assets-CAPEX relationship is significant $(\beta=-0.04, p<0.05)$, total sales-CAPEX is insignificant $(\beta=-0.01$, ns) and MVE-CAPEX relationship is also insignificant $(\beta=-0.0001, \mathrm{~ns})$. The value of $R^{2}$ for these models was 0.09 . These results thus support hypothesis $\mathrm{H} 3$.

\section{Firm size and diversification}

Table 7 shows results for pooled OLS of firm size measures on number of business segments. Leverage and performance are the control variables. Results as shown in the table indicate that firm size as measured by total assets is significantly related to business segments of firm $(\beta=0.0731, p<0.05)$ and total sales-business segments relationship is also significant $(\beta=0.058, p<0.05)$. There exists insignificant relationship between MVE and business segments $(\beta=0.032$, ns) and number of employees and number of business segments $(\beta=0.0057$, ns). Value of $R^{2}$ for all these four models was $0.06,0.06,0.05$ and 0.05 , respectively. Results of random effect show that there exists significant relationship between firm size as measured by number of employees and number of business segments $(\beta=-0.123, p<0.01)$. Relationship between total sales and number of business segments is also significant $(\beta=0.055, p<0.1)$, relationship of MVE and number of business segments is significant $(\beta=0.0309, p<0.1)$ and total assets and number of business segments is insignificant $(\beta=0.0232$, ns). The value of $R^{2}$ for these models was $0.03,0.03,0.02$ and 0.06 approximately. These results support hypothesis H4.

\section{Firm size and firm performance}

The table shows results for pooled OLS of firm size measures on ROA. Business segments and debt-equity ratio are the control variables. Results as shown in Table 8 indicate that all proxies are significantly related to ROA: total assets and ROA $(\beta=-1.18, p<0.01)$, MVE-ROA 
Table 4 Results of Hausman test

\begin{tabular}{|c|c|c|c|c|}
\hline & Chi-square & d.f & $p$ value & Decision \\
\hline \multicolumn{5}{|c|}{ Financial leverage (assets to equity) } \\
\hline Size: Ln (total asset) & 3.15 & 2.00 & 0.21 & Random Effect \\
\hline Size: Ln (total sales) & 30.62 & 2.00 & 0.00 & Fixed effect \\
\hline Size: Ln (MVE) & 7.12 & 2.00 & 0.03 & Fixed effect \\
\hline $\begin{array}{l}\text { Size: number of employ- } \\
\text { ees }\end{array}$ & 9.71 & 2.00 & 0.01 & Fixed effect \\
\hline \multicolumn{5}{|c|}{ Financial leverage (debt to equity) } \\
\hline Size: Ln (total asset) & 14.61 & 3.00 & 0.00 & Fixed effect \\
\hline Size: Ln (total sales) & 7.48 & 3.00 & 0.06 & Fixed effect \\
\hline Size: Ln (MVE) & 21.36 & 3.00 & 0.00 & Fixed effect \\
\hline $\begin{array}{l}\text { Size: number of employ- } \\
\text { ees }\end{array}$ & 1.94 & 3.00 & 0.58 & Random effect \\
\hline \multicolumn{5}{|l|}{ CAPEX } \\
\hline Size: Ln (total asset) & 9.90 & 2.00 & 0.01 & Fixed effect \\
\hline Size: Ln (total sales) & 15.71 & 2.00 & 0.00 & Fixed effect \\
\hline Size: Ln (MVE) & 15.89 & 2.00 & 0.00 & Fixed effect \\
\hline $\begin{array}{l}\text { Size: number of employ- } \\
\text { ees }\end{array}$ & 19.30 & 2.00 & 0.00 & Fixed effect \\
\hline \multicolumn{5}{|l|}{ Business segment } \\
\hline Size: Ln (total asset) & 2.24 & 3.00 & 0.52 & Random effect \\
\hline Size: Ln (total sales) & 2.19 & 3.00 & 0.53 & Random effect \\
\hline Size: $\operatorname{Ln}(M V E)$ & 5.83 & 3.00 & 0.12 & Random effect \\
\hline $\begin{array}{l}\text { Size: number of employ- } \\
\text { ees }\end{array}$ & 6.64 & 3.00 & 0.08 & Random effect \\
\hline \multicolumn{5}{|l|}{$\mathrm{ROA}$} \\
\hline Size: Ln (total asset) & 313.37 & 3.00 & 0.00 & Fixed effect \\
\hline Size: Ln (total sales) & 217.43 & 3.00 & 0.00 & Fixed effect \\
\hline Size: Ln (MVE) & 409.33 & 3.00 & 0.00 & Fixed effect \\
\hline $\begin{array}{l}\text { Size: number of employ- } \\
\text { ees }\end{array}$ & 13.40 & 3.00 & 0.00 & Fixed effect \\
\hline \multicolumn{5}{|l|}{$\mathrm{ROE}$} \\
\hline Size: Ln (total asset) & 460.89 & 3.00 & 0.00 & Fixed effect \\
\hline Size: Ln (total sales) & 415.57 & 3.00 & 0.00 & Fixed effect \\
\hline Size: Ln (MVE) & 458.01 & 3.00 & 0.00 & Fixed effect \\
\hline $\begin{array}{l}\text { Size: number of employ- } \\
\text { ees }\end{array}$ & 45.95 & 3.00 & 0.00 & Fixed effect \\
\hline \multicolumn{5}{|l|}{ Independent directors } \\
\hline Size: Ln (total asset) & 4.05 & 3.00 & 0.26 & Random effect \\
\hline Size: Ln (Total Sales) & 2.14 & 3.00 & 0.54 & Random effect \\
\hline Size: Ln (MVE) & 8.15 & 3.00 & 0.04 & Random effect \\
\hline $\begin{array}{l}\text { Size: number of employ- } \\
\text { ees }\end{array}$ & 36.58 & 3.00 & 0.00 & Fixed effect \\
\hline \multicolumn{5}{|l|}{ Non-executive directors } \\
\hline Size: Ln (total asset) & 53.01 & 3.00 & 0.00 & Fixed effect \\
\hline Size: Ln (total sales) & 15.67 & 3.00 & 0.00 & Fixed effect \\
\hline Size: $\operatorname{Ln}(\mathrm{MVE})$ & 54.97 & 3.00 & 0.00 & Fixed effect \\
\hline $\begin{array}{l}\text { Size: number of employ- } \\
\text { ees }\end{array}$ & 106.51 & 3.00 & 0.00 & Fixed effect \\
\hline
\end{tabular}

relationship $(\beta=-1.24, p<0.01)$, total sales and ROA $(\beta=-1.23, p<0.01)$ and number of employees and ROA $(\beta=0.95, p<0.01)$. Value of $R^{2}$ for all these four models was $0.08,0.08,0.07$ and 0.03 , respectively, for total asset-ROA, total sales-ROA, MVE-ROA and number of employees-ROA.

Results of Hausman test as shown in Table 4 show that fixed effect regression is appropriate for all models. Results of fixed effect are also mentioned in Table 8 . The table shows that there exists significant relationship between firm size as measured by total assets and ROA $(\beta=0.20, p<0.01)$. The relationship between firm size as measured by total sales and ROA is insignificant $(\beta=-0.84, p<0.01)$. The relationship of firm size as measured by MVE and ROA is significant $(\beta=0.39$, $p<0.01)$. The relationship between firm size as measured by number of employees and ROA is also significant $(\beta=0.56, p<0.01)$. The value of $R^{2}$ for these models was $0.08,0.07,0.09$ and 0.09 approximately, respectively. In case of ROE as DV, pooled OLS regression as shown in Table 9 shows that all proxies are significantly related to ROE: total asset $(\beta=-1.05, p<0.01)$, total sales $(\beta=-1.10, p<0.01), \operatorname{MVE}(\beta=-1.12, p<0.01)$ and number of employees $(\beta=0.84, p<0.01)$. Value of $R^{2}$ for all these four models was $0.08,0.08,0.07$ and 0.03 , respectively, for total asset-ROE, total sales-ROE, MVE-ROE and number of employees-ROE.

Results of Hausman test as shown in Table 4 show that fixed effect regression is appropriate in all models. Results of fixed effect are also mentioned in Table 9. The table shows that total asset-ROE relationship is significant $(\beta=0.11, p<0.01)$, total sales-ROE relationship is insignificant $(\beta=-0.03, \mathrm{~ns})$, MVE-ROE relationship is significant $(\beta=0.11, p<0.01)$ and number of employeeROE relationship is significant $(\beta=0.17, p<0.01)$. The value of $R^{2}$ for model 5, i.e. total assets-ROE, is 0.08 , for model 6 , i.e. total sales-ROE, it is 0.08 , for model 7 , i.e. MVE-ROE, is 0.09 and for model 8 , i.e. number of employees-ROE, is 0.09 . Support for hypothesis H5 is thus found from this result.

\section{Firm size and board structure}

Table 10 shows results for pooled OLS of firm size measures on number of independent directors. Business segments and performance are the control variables. Results as shown in the table indicate that firm size as measured by total assets is significantly related to number of independent directors $(\beta=0.03, p<0.05)$. It can also be seen that number of employees-number of independent directors relationship $(\beta=0.09$, $p<0.01)$ and MVE and number of independent directors relationship $(\beta=0.05, \quad p<0.01)$.are significant. There exists an insignificant relationship between total 
Table 5 Regression analysis of firm size (total asset, total sales, MVE and number of employees) and financial leverage (debt to equity)

\begin{tabular}{|c|c|c|c|c|c|c|c|c|}
\hline & (1) & (2) & (3) & (4) & (5) & (6) & (7) & (8) \\
\hline & Pooled OLS & Pooled OLS & Pooled OLS & Pooled OLS & $\mathrm{FE}$ & $\mathrm{FE}$ & $\mathrm{FE}$ & RE \\
\hline C & $0.10^{\mathrm{ns}}$ & $0.08^{\mathrm{ns}}$ & $0.43^{* * *}$ & $0.48^{* * *}$ & $-0.69^{* * *}$ & $-0.19^{\mathrm{ns}}$ & $0.09^{\text {ns }}$ & $0.56^{* * *}$ \\
\hline Profitability: ROA & $0.05^{* * *}$ & $0.06^{* * *}$ & $0.02^{* * *}$ & $-0.01^{* *}$ & $0.11^{* * *}$ & $0.08^{* * *}$ & $0.05^{* * *}$ & $-0.01^{\mathrm{ns}}$ \\
\hline Tangibility & $0.00^{\text {ns }}$ & $0.00^{\mathrm{ns}}$ & $0.00^{\mathrm{ns}}$ & $0.00^{\mathrm{ns}}$ & $0.00^{\text {ns }}$ & $0.00^{\text {ns }}$ & $0.00^{\mathrm{ns}}$ & $0.00^{\text {ns }}$ \\
\hline Size: Ln(assets) & $0.07^{* * *}$ & & & & $0.21^{* * *}$ & & & \\
\hline Size: Ln(sales) & & $0.08^{* * *}$ & & & & $0.11^{* * *}$ & & \\
\hline Size: $\operatorname{Ln}(M V E)$ & & & $0.03^{* * *}$ & & & & $0.06^{* * *}$ & \\
\hline Size: number of employees & & & & $0.03^{* * *}$ & & & & $0.02^{\mathrm{ns}}$ \\
\hline Year fixed effect & Yes & Yes & Yes & Yes & Yes & Yes & Yes & Yes \\
\hline$R^{2}$ & 0.04 & 0.04 & 0.03 & 0.09 & 0.04 & 0.05 & 0.02 & 0.12 \\
\hline \#Observations & 1250 & 1250 & 1250 & 1250 & 1250 & 1250 & 1250 & 1250 \\
\hline
\end{tabular}

F test

Chi2(3) $=7.41$

$p$ value $=0.041$

Explanatory variable: debt to equity (TD/TE)

Models (1)-(4) represent simple pooled OLS results, i.e. common effect

Models (5)-(8) represent fixed/random effect regression based on results of Hausman test stated above

$*{ }^{* * *},{ }^{* *},{ }^{*}$ represent $1 \%, 5 \%$ and $10 \%$ level of significance, respectively; ns represents not significant

Table 6 Regression analysis of firm size (total asset, total sales, MVE and number of employees) and CAPEX

\begin{tabular}{|c|c|c|c|c|c|c|c|c|}
\hline & (1) & (2) & (3) & (4) & (5) & (6) & (7) & (8) \\
\hline & Pooled OLS & Pooled OLS & Pooled OLS & Pooled OLS & FE & $\mathrm{FE}$ & $\mathrm{FE}$ & $\mathrm{FE}$ \\
\hline C & $0.90^{* * *}$ & $0.86^{* * *}$ & $1.00^{* * *}$ & $-0.32^{* * *}$ & $0.85^{* * *}$ & $0.76^{* * *}$ & $0.75^{* * *}$ & $0.72^{* * *}$ \\
\hline Leverage & $0.05^{*}$ & $0.06^{* *}$ & $0.04^{\mathrm{ns}}$ & $-0.01^{\mathrm{ns}}$ & $0.00^{\text {ns }}$ & $0.00^{\text {ns }}$ & $-0.001^{\mathrm{ns}}$ & $-0.001^{\mathrm{ns}}$ \\
\hline Size: Ln(assets) & $-0.08^{* * *}$ & & & & $-0.04^{* *}$ & & & \\
\hline Size: Ln(sales) & & $-0.09^{* * *}$ & & & & $-0.01^{\mathrm{ns}}$ & & \\
\hline Size: $\operatorname{Ln}(M V E)$ & & & $-0.08^{* * *}$ & & & & $-0.0001^{\mathrm{ns}}$ & \\
\hline Size: number of employees & & & & $0.09^{* * *}$ & & & & $0.002^{\text {ns }}$ \\
\hline Year fixed effect & Yes & Yes & Yes & Yes & Yes & Yes & Yes & Yes \\
\hline$R^{2}$ & 0.18 & 0.19 & 0.17 & 0.14 & 0.09 & 0.09 & 0.09 & 0.09 \\
\hline \#Observations & 1250 & 1250 & 1250 & 1250 & 1250 & 1250 & 1250 & 1250 \\
\hline
\end{tabular}

F test

Chi2(3) $=10.49$

$p$ value $=0.01$

Explanatory variable: CAPEX (net capital expenditure scaled by total assets)

Models (1)-(4) represent simple pooled OLS results, i.e. common effect

Models (5)-(8) represent fixed/random effect regression based on results of Hausman test stated above

$* * * * * * *$ represent $1 \%, 5 \%$ and $10 \%$ level of significance, respectively; $\mathrm{ns}$ represents not significant

sales and number of independent directors $(\beta=0.02$, $\mathrm{ns})$. Value of $R^{2}$ for all these four models was 0.15 , $0.15,0.16$ and 0.29 , respectively, for total asset-number of independent directors, total sales-number of independent directors, MVE-number of independent directors and number of employees-number of independent directors.
Results of Hausman test for board structure and firm size are shown in Table 4. Results of Hausman test as shown in the table indicate that random effect regression is appropriate for MVE-independent director relationship and number of employees-number of independent directors relationship, and fixed effect is better in rest of two. Results of fixed/random effect are also mentioned in 
Table 7 Regression analysis of firm size (total asset, total sales, MVE and number of employees) and diversification

\begin{tabular}{|c|c|c|c|c|c|c|c|c|}
\hline & $(1)$ & $(2)$ & (3) & (4) & (5) & (6) & (7) & (8) \\
\hline & Pooled OLS & Pooled OLS & Pooled OLS & Pooled OLS & RE & RE & RE & RE \\
\hline C & $0.92^{* * *}$ & $0.72^{* * *}$ & $1.10^{* * *}$ & $0.82^{* * *}$ & $0.55^{* *}$ & $0.55^{* * *}$ & $0.13^{\mathrm{ns}}$ & $1.01^{* *}$ \\
\hline Leverage & $-0.13^{* *}$ & $-0.12^{* *}$ & $-0.10^{*}$ & $-0.11^{* *}$ & $-0.04^{\mathrm{ns}}$ & $-0.04^{\mathrm{ns}}$ & $-0.02^{n s}$ & $-0.02^{\mathrm{ns}}$ \\
\hline Performance & $-0.01^{\mathrm{ns}}$ & $0.00^{\text {ns }}$ & $-0.03^{*}$ & $-0.01^{\mathrm{ns}}$ & $0.01^{\mathrm{ns}}$ & $0.01^{\text {ns }}$ & $0.02^{\mathrm{ns}}$ & $0.08^{* *}$ \\
\hline Size: Ln(assets) & $0.073^{* *}$ & & & & $0.023^{\text {ns }}$ & & & \\
\hline Size: Ln(sales) & & $0.058^{* *}$ & & & & $0.055^{*}$ & & \\
\hline Size: Ln(MVE) & & & $-0.03^{\mathrm{ns}}$ & & & & $0.0309^{*}$ & \\
\hline Size: number of employees & & & & $0.0057^{\mathrm{ns}}$ & & & & $0.123^{* * *}$ \\
\hline Year fixed effect & Yes & Yes & Yes & Yes & Yes & Yes & Yes & Yes \\
\hline$R^{2}$ & 0.06 & 0.06 & 0.05 & 0.05 & 0.03 & 0.03 & 0.02 & 0.06 \\
\hline \#Observations & 1250 & 1250 & 1250 & 1250 & 1250 & 1250 & 1250 & 1250 \\
\hline \multicolumn{9}{|l|}{$F$ test } \\
\hline \multicolumn{9}{|l|}{ Chi2(3) $=21.58$} \\
\hline \multicolumn{9}{|l|}{$p$ value $=0.000$} \\
\hline \multicolumn{9}{|c|}{ Explanatory variable: number of business segment (Ln business seg) } \\
\hline \multicolumn{9}{|c|}{ Models (1)-(4) represent simple pooled OLS results, i.e. common effect } \\
\hline \multicolumn{9}{|c|}{ Models (5)-(8) represent fixed/random effect regression based on results of Hausman test stated above } \\
\hline$*^{* *},{ }^{* *},{ }^{*}$ represent $1 \%, 5 \%$ and 1 & $\%$ level of signific & e, respectively; & ents not s & ant & & & & \\
\hline
\end{tabular}

Table 8 Regression analysis of firm size (total asset, total sales, MVE and number of employees) and ROA

\begin{tabular}{|c|c|c|c|c|c|c|c|c|}
\hline & (1) & $(2)$ & (3) & (4) & (5) & (6) & (7) & (8) \\
\hline & Pooled OLS & Pooled OLS & Pooled OLS & Pooled OLS & FE & FE & FE & FE \\
\hline C & $11.26^{* * *}$ & $10.57^{* * *}$ & $12.85^{* * *}$ & $-2.46^{* * *}$ & $8.12^{* * *}$ & $10.08^{* * *}$ & $7.28^{* * *}$ & $1.77^{* * *}$ \\
\hline Log (segments) & $-0.02^{n s}$ & $0.01^{\mathrm{ns}}$ & $-0.10^{*}$ & $-0.13^{\mathrm{ns}}$ & $0.02^{\mathrm{ns}}$ & $0.02^{\mathrm{ns}}$ & $0.01^{\text {ns }}$ & $0.04^{* *}$ \\
\hline Debt/equity & $0.59 * * *$ & $0.64^{* * *}$ & $0.31^{* * *}$ & $-0.33^{*}$ & $0.27^{* * *}$ & $0.34^{* * *}$ & $0.29 * * *$ & $0.20^{* * *}$ \\
\hline Size: Ln(assets) & $-1.18^{* * *}$ & & & & $0.20^{* * *}$ & & & \\
\hline Size: Ln(sales) & & $-1.23^{* * *}$ & & & & $-0.84^{* * *}$ & & \\
\hline Size: Ln(MVE) & & & $-1.24^{* * *}$ & & & & $0.39^{* * *}$ & \\
\hline Size: number of employees & & & & $0.95^{* * *}$ & & & & $0.56^{* * *}$ \\
\hline Year fixed effect & Yes & Yes & Yes & Yes & Yes & Yes & Yes & Yes \\
\hline$R^{2}$ & 0.08 & 0.08 & 0.07 & 0.03 & 0.08 & 0.07 & 0.09 & 0.09 \\
\hline \#Observations & 1250 & 1250 & 1250 & 1250 & 1250 & 1250 & 1250 & 1250 \\
\hline
\end{tabular}

F test

Chi2(3) $=9.79$

$p$ value $=0.000$

Explanatory variable: return on assets (ROA)

Models (1)-(4) represent simple pooled OLS results, i.e. common effect

Models (5)-(8) represent fixed/random effect regression based on results of Hausman test stated above

$* * * * *,{ }^{*}$ represent $1 \%, 5 \%$ and $10 \%$ level of significance, respectively; $n$ s represents not significant

Table 10. The table shows that there exists insignificant relationship between firm size as measured by number of employees and number of independent directors $(\beta=-0.01, \mathrm{~ns})$. All other models are insignificant: total assets and number of independent directors $(\beta=0.04$, $p<0.01)$, sales and number of independent directors $(\beta=0.03, p<0.05)$ and MVE and number of independent directors $(\beta=0.09, p<0.01)$. The value of $R^{2}$ for all of these models was $0.14,0.14,0.08$ and 0.09 for models 5 , 6, 7 and 8, respectively. In case of NEDs as DV, pooled OLS regression as shown in Table 11 shows that all proxies are significantly related to number of non-executive directors, i.e. total assets $(\beta=0.18, p<0.01)$, total sales $(\beta=0.20, p<0.01)$, MVE $(\beta=0.16, p<0.01)$ and number 
Table 9 Regression analysis of firm size (total asset, total sales, MVE and number of employees) and ROE

\begin{tabular}{|c|c|c|c|c|c|c|c|c|}
\hline & $(1)$ & $(2)$ & (3) & (4) & $(5)$ & (6) & (7) & (8) \\
\hline & Pooled OLS & Pooled OLS & Pooled OLS & Pooled OLS & FE & FE & FE & FE \\
\hline C & $10.62^{* * *}$ & $10.04^{* * *}$ & $11.91^{* * *}$ & $-2.28^{* * *}$ & $7.75^{* * *}$ & $7.95^{* * *}$ & $7.63^{* * *}$ & $5.88^{* * *}$ \\
\hline Log (segments) & $0.00^{\mathrm{ns}}$ & $0.02^{\mathrm{ns}}$ & $-0.05^{*}$ & $-0.16^{\mathrm{ns}}$ & $0.03^{* *}$ & $0.03^{* *}$ & $0.03^{*}$ & $0.03^{* *}$ \\
\hline Debt/equity & $-1.51^{* *}$ & $-1.34^{* *}$ & $-1.94^{* *}$ & $3.27^{* *}$ & $-0.16^{\mathrm{ns}}$ & $-0.16^{\mathrm{ns}}$ & $-0.15^{\mathrm{ns}}$ & $0.02^{\text {ns }}$ \\
\hline Size: Ln(assets) & $-1.05^{* * *}$ & & & & $0.11^{* * *}$ & & & \\
\hline Size: Ln(sales) & & $-1.10^{* * *}$ & & & & $0.03^{\text {ns }}$ & & \\
\hline Size: $\operatorname{Ln}(M V E)$ & & & $-1.12^{* * *}$ & & & & $0.11^{* * *}$ & \\
\hline Size: number of employees & & & & $0.84^{* * *}$ & & & & $0.17^{* * *}$ \\
\hline Year fixed effect & Yes & Yes & Yes & Yes & Yes & Yes & Yes & Yes \\
\hline$R^{2}$ & 0.08 & 0.08 & 0.07 & 0.03 & 0.08 & 0.08 & 0.09 & 0.09 \\
\hline \#Observations & 1250 & 1250 & 1250 & 1250 & 1250 & 1250 & 1250 & 1250 \\
\hline \multicolumn{9}{|l|}{$F$ test } \\
\hline \multicolumn{9}{|l|}{ Chi2(3) $=44.68$} \\
\hline \multicolumn{9}{|c|}{$p$ value $=0.000$} \\
\hline \multicolumn{9}{|c|}{ Explanatory variable: return on equity $(\mathrm{ROE})$} \\
\hline \multicolumn{9}{|c|}{ Models (1)-(4) represent simple pooled OLS results, i.e. common effect } \\
\hline \multicolumn{9}{|c|}{ Models (5)-(8) represent fixed/random effect regression based on results of Hausman test stated above } \\
\hline$* * * * * * *$ represent $1 \%, 5 \%$ and 1 & $\%$ level of signific & e, respectively; $n$ & epresents not sic & & & & & \\
\hline
\end{tabular}

Table 10 Regression analysis of firm size (total asset, total sales, MVE and number of employees) and independent director

\begin{tabular}{|c|c|c|c|c|c|c|c|c|}
\hline & (1) & $(2)$ & (3) & (4) & (5) & (6) & (7) & (8) \\
\hline & Pooled OLS & Pooled OLS & Pooled OLS & Pooled OLS & RE & $\mathrm{RE}$ & RE & FE \\
\hline C & $0.76^{* * *}$ & $0.87^{* * *}$ & $0.59^{* * *}$ & $0.13^{* * *}$ & $0.63^{* * *}$ & $0.70^{* * *}$ & $0.52^{* * *}$ & $0.82^{* * *}$ \\
\hline Log (segments) & $-0.04^{* * *}$ & $-0.04^{* * *}$ & $-0.04^{* * *}$ & $-0.04^{* * *}$ & $0.00^{\text {ns }}$ & $0.00^{\mathrm{ns}}$ & $-0.01^{\mathrm{ns}}$ & $0.00^{\mathrm{ns}}$ \\
\hline Performance & $0.06^{* * *}$ & $0.06^{* * *}$ & $0.07^{* * *}$ & $0.01 * * *$ & $0.07^{* * *}$ & $0.07^{* * *}$ & $0.06^{* * *}$ & $0.08^{* * *}$ \\
\hline Size: Ln(assets) & $0.03^{* *}$ & & & & $0.04^{* * *}$ & & & \\
\hline Size: Ln(sales) & & $0.02^{\text {ns }}$ & & & & $0.03^{* *}$ & & \\
\hline Size: Ln(MVE) & & & $0.05^{* * *}$ & & & & $0.09^{* * *}$ & \\
\hline Size: number of employees & & & & $0.09 * * *$ & & & & $-0.01^{\mathrm{ns}}$ \\
\hline Year fixed effect & Yes & Yes & Yes & Yes & Yes & Yes & Yes & Yes \\
\hline$R^{2}$ & 0.15 & 0.15 & 0.16 & 0.29 & 0.14 & 0.14 & 0.08 & 0.09 \\
\hline \#Observations & 1250 & 1250 & 1250 & 1250 & 1250 & 1250 & 1250 & 1250 \\
\hline
\end{tabular}

F test

Chi2(3) $=97.6$

$p$ value $=0.000$

Explanatory variable: independent directors on board (Ln Ind Dir)

Models (1)-(4) represent simple pooled OLS results, i.e. common effect

Models (5)-(8) represent fixed/random effect regression based on results of Hausman test stated above

$* * *, * * *$ represent $1 \%, 5 \%$ and $10 \%$ level of significance, respectively; ns represents not significant

of employees $(\beta=0.03, p<0.01)$. The value of $R^{2}$ for these relationships was $0.07,0.08,0.07$ and 0.06 , respectively.

Results of Hausman test as shown in Table 4 indicate that fixed effect regression is appropriate in all cases. Results of fixed effect are also mentioned in Table 11. The table shows that all proxies are significantly related to number of non-executive directors, i.e. total assets $(\beta=0.16, p<0.01)$, total sales $(\beta=0.11, p<0.01)$, MVE $(\beta=0.15, p<0.01)$ and number of employees $(\beta=0.04$, $p<0.01$ ). The value of $R^{2}$ for these relationships was 0.07 , $0.08,0.08$ and 0.09 , respectively. Hypothesis $\mathrm{H} 7$ is thus supported. 
Table 11 Regression analysis of firm size (total asset, total sales, MVE and number of employees) and non-executive directors

\begin{tabular}{|c|c|c|c|c|c|c|c|c|}
\hline & (1) & $(2)$ & (3) & (4) & (5) & (6) & (7) & (8) \\
\hline & Pooled OLS & Pooled OLS & Pooled OLS & Pooled OLS & $\mathrm{FE}$ & $\mathrm{FE}$ & $\mathrm{FE}$ & $\mathrm{FE}$ \\
\hline C & $0.30^{* * *}$ & $0.34^{* * *}$ & $0.40^{* * *}$ & $1.59^{* * *}$ & $0.45^{* * *}$ & $0.38^{* * *}$ & $0.49^{* * *}$ & $0.29^{* *}$ \\
\hline Log (segments) & $-0.05^{* * *}$ & $-0.05^{* * *}$ & $-0.04^{* * *}$ & $-0.05^{* * *}$ & $-0.07^{* * *}$ & $-0.08^{* * *}$ & $-0.07^{* * *}$ & $-0.08^{* * *}$ \\
\hline Performance & $-0.02^{* * *}$ & $-0.01^{* *}$ & $-0.04^{* * *}$ & $-0.15^{* * *}$ & $-0.03^{* * *}$ & $0.00^{\text {ns }}$ & $-0.04^{* * *}$ & $-0.02^{\mathrm{ns}}$ \\
\hline Size: Ln(assets) & $0.18^{* * *}$ & & & & $0.16^{* * *}$ & & & \\
\hline Size: Ln(sales) & & $0.20^{* * *}$ & & & & $0.11^{* * *}$ & & \\
\hline Size: Ln(MVE) & & & $0.16^{* * *}$ & & & & $0.15^{* * *}$ & \\
\hline Size: number of employees & & & & $0.03^{* * *}$ & & & & $0.04^{* * *}$ \\
\hline Year fixed effect & Yes & Yes & Yes & Yes & Yes & Yes & Yes & Yes \\
\hline$R^{2}$ & 0.07 & 0.08 & 0.07 & 0.06 & 0.07 & 0.08 & 0.08 & 0.09 \\
\hline \#Observations & 1250 & 1250 & 1250 & 1250 & 1250 & 1250 & 1250 & 1250 \\
\hline
\end{tabular}

F test

Chi2(3) $=12.91$

$p$ value $=0.000$

Explanatory variable: non-executive directors on board (Ln NED)

Models (1)-(4) represent simple pooled OLS results, i.e. common effect

Models (5)-(8) represent fixed/random effect regression based on results of Hausman test stated above

$* *^{*}, * *, *$ represent $1 \%, 5 \%$ and $10 \%$ level of significance, respectively; ns represents not significant

\section{Firm size and dividend policy}

Dividend policy was a dummy variable, i.e. its value is 1 if a firm pays dividend and 0 if it does not. Results for logit and logistic regression are reported in Table 12 for both dummy dependent variables, i.e. dividend policy and pay level.

Results as shown in Table 12 show that firm size as measured by total assets is insignificantly related to dividend policy $(\beta=0.013, \mathrm{~ns})$. For total sales as measure of firm size, results are also same, i.e. insignificant $(\beta=0.045$, ns). Relationship between MVE and dividend policy is significant $(\beta=0.136, p<0.01)$. The last proxy of firm size taken by this study, i.e. number of employees, is significantly related to dividend policy $(\beta=0.185, p<0.01)$ and positive. Pseudo- $R^{2}$ values for these models were $0.001,0.001,0.02$ and 0.019 , respectively. These results thus support hypothesis H2.

\section{Firm size and pay level}

Pay level was also a dummy variable. Results for this variable are also shown in Table 12. These results show that all proxies are significantly related to pay level, i.e. total assets $(\beta=0.71, p<0.01)$, total sales $(\beta=0.53 p<0.01)$, MVE $(\beta=0.51, \quad p<0.01)$ and number of employees $(\beta=0.21, p<0.01)$. Value of $R^{2}$ for these relationships was $0.18,0.16,0.20$ and 0.02 , respectively. Odds ratio reveals a positive relationship between all relationships. These results are thus supporting hypothesis $\mathrm{H} 6$.

\section{Sensitivity of firm size measures}

Tables 13 and 14 show sensitivity of firm size measures with different practices of corporate finance based on pooled OLS and fixed effect regression, respectively, for South Africa. As hypothesized in H8, results show that different measures of firm size are differently related to different practices. Results show that although results are

Table 12 Regression analysis of dummy dependent variables

\begin{tabular}{|c|c|c|c|c|c|c|c|c|}
\hline & \multicolumn{4}{|c|}{ Dividend policy } & \multicolumn{4}{|l|}{ Pay level } \\
\hline & Coefficient & Odds ratio & $p>|z|$ & $R^{2}$ & Coefficient & Odds ratio & $p>|z|$ & $R^{2}$ \\
\hline Total assets & .013 & 1.01 & 0.70 & 0.001 & .71 & 2.02 & 0.00 & 0.18 \\
\hline Total sales & .045 & 1.05 & 0.19 & 0.001 & .53 & 1.70 & 0.00 & 0.16 \\
\hline MVE & .136 & 1.15 & 0.00 & 0.02 & .51 & 1.66 & 0.00 & 0.20 \\
\hline Number of employees & .185 & 1.20 & 0.00 & 0.019 & .21 & 1.24 & 0.00 & 0.02 \\
\hline
\end{tabular}

Dependent variable: dividend policy (Dummy); pay level (Dummy), $n=1250$ 


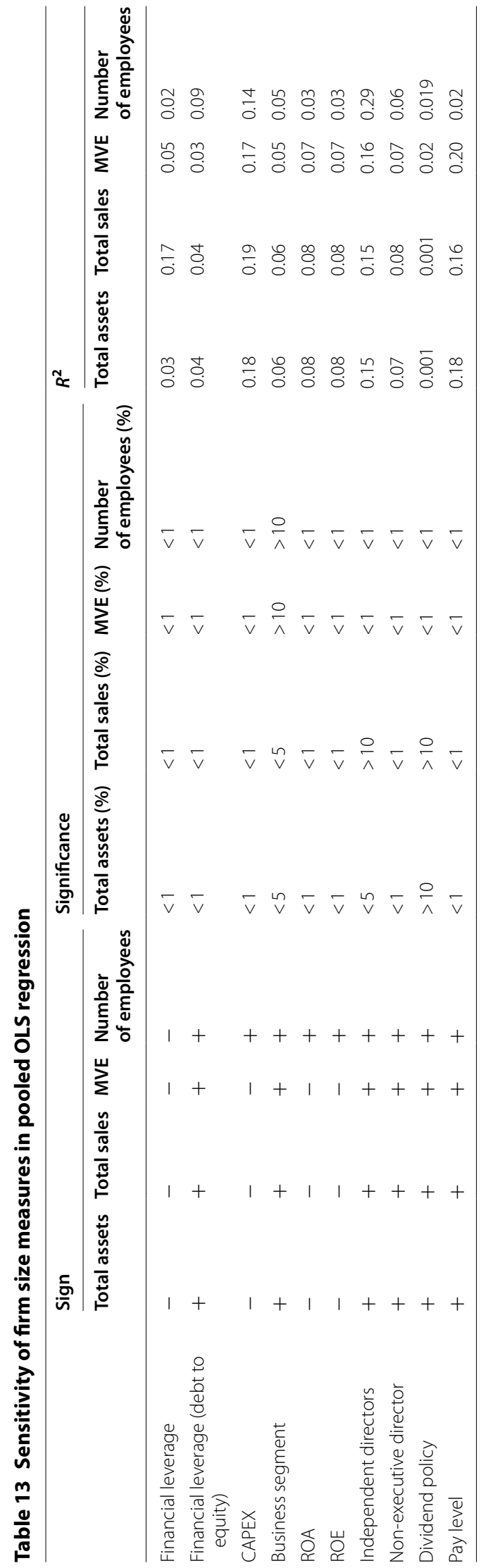




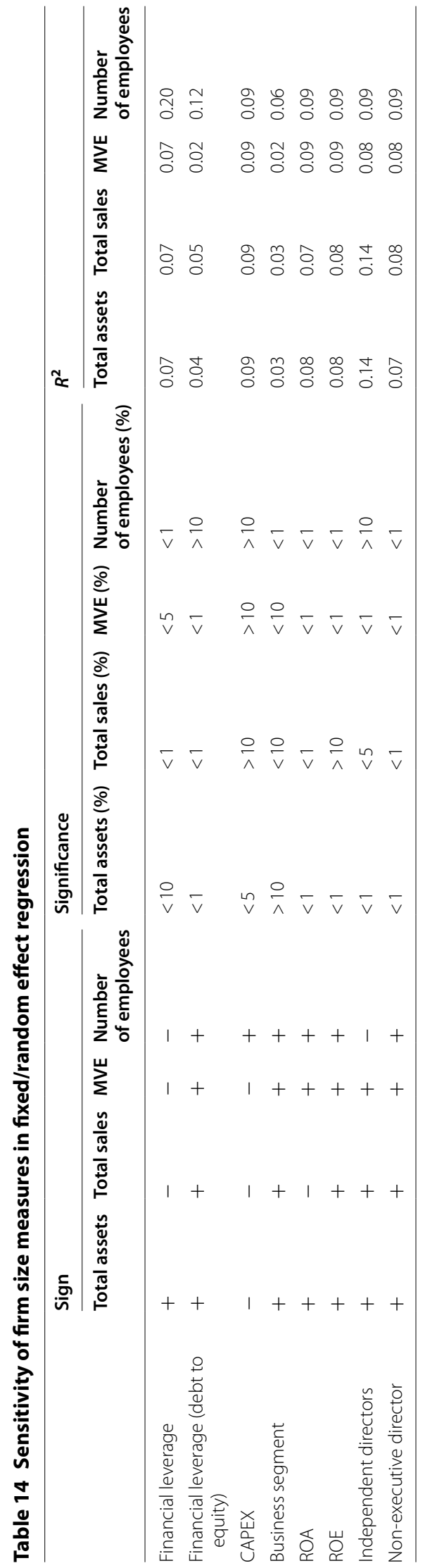


robust in sign and significance in most cases, firm size does change its sign from proxy to another even for a same area. These results are thus supporting hypothesis $\mathrm{H} 8$ and have serious implications.

\section{Robustness test}

For robustness issue, we used firm fixed effect regression as suggested by Dang et al. [30]. Although none of the papers in the field have applied GMM to look for dynamic modelling, we applied GMM to test for dynamic modelling. Our results of GMM however forced us to stick with original OLS estimates.

\section{Discussions}

This study was done with the purpose of determining impact of different measures of firm size on seven important areas of corporate finance. Besides examining this impact of proxies on major practices of corporate finance, another major objective of the study was to check the sensitivity of different proxies of firm size on practices of corporate finance. Practices were financial policy, dividend policy, investment policy, diversification, firm performance, compensation and incentives and board structure (corporate governance).

Overall, the results indicate that firm size is significantly related to these areas of corporate finance. More importantly, results show that different measures of firm size are differently related to these areas. This difference can be seen in the beta coefficient value. It can also be seen that in some cases, for one practice different measures of firm size have different signs of coefficient meaning that they are differently related to that practice, i.e. one might be positive, and the other proxy is negatively related to that practice. Similarly, each proxy has different explanatory powers towards each practice of corporate finance (in most cases). This means that different proxies have different relationship towards different areas of corporate finance.

Previous studies have also pointed out that these different proxies of firm size are different concepts and thus cannot be replaced with each other (e.g. see [30, 31]). This means that a proxy which is more related to the concept should be used while examining firm size in relation to that practice. Firm size has been examined in almost every field. A lot of research has either examined it as explanatory variable or control variable, but the issue with past research is that use of proxy of firm size in that context is not well justified, e.g. consider a study on financial policy which used number of employees as a proxy of firm size, while number of employees may be the least statistically related proxy of firm size with financial policy. Unfortunately, this may suggest that some research of past in this area is not robust and may have biased results.
The first hypothesis of the study was that firm size has a significant impact on financial policy. This hypothesis has been supported by the results. Our result is in line with the previous research done in this area (e.g. [28, 34, 67]). Theoretically, the relationship between size and financial policy also seems justifiable. With the increase in size of firm, total assets of that firm also increase which will increase the financial leverage of firm. Similarly, large firms need more financing than small firms; they might have large operations and more projects for which they require funds which cannot be met only from the internal resources. Large firms thus need to move towards external financing. Debt is undoubtedly the cheapest and easily available source of financing. Large firms thus will be more levered than small firms. Small firms may be family owned, or if not, they might only be revolving around certain people; they can even be a total equity financed firm. It is thus rational to think that large firms are more levered than small firms and thus moving from smaller to larger firms will change the financial policy of the firm.

The second hypothesis of the study was that firm size has a significant impact on dividend policy. This hypothesis has also been supported. This result is in line with the previous research in this area, e.g. [25-27] have all found a significant relationship between size of a firm and dividend policy. Large firms pay more dividend than smaller firms. The explanation of this result may be supported from signalling theory of Ross [68]. According to signalling concept, large firms will give off more dividends to give a positive signal to the market about the financial health of the company. Paying dividend will boost the confidence of market and investor on the firm, and a continuous policy of paying dividend will also help investor to distinguish between poor performing firms which may give dividend to show that they are performing well (which actually they are not) and a good firm. As large firms have more resources, they should and they do continue to pay dividend to give good signal to the market. Take it from the perspective of agency cost theory of Jensen and Meckling [40]. From agency argument, as with the rise in size of firm, agency cost increases; dividends act as a protection for investors because dividends reduce the excess cash available to managers after investment and operating activities. So, in order to reduce agency problem, large firms do give more dividends.

The third hypothesis of the study was that firm size has a significant impact on investment policy. Results support this hypothesis too. Rise of firm in size demands more expansion of firm's operations either geographically or in products or services it is rendering. This expansion is not cost free. Expansion of business requires resources, money above all. Thus, moving from small to large firm's investment expenditures increases. Large firms make 
more investments in form of plant, property and equipment. Prerequisite to CAPEX that is capital expenditure done for investment are the investment appraisal techniques, i.e. NPV, IRR, etc. These appraisal techniques are all costly and represent sunk cost. Affording such highcost techniques just to examine the profitability of a new venture is not possible for small firms. Researchers in past have also shown that the use of these techniques by a firm is size dependent (e.g. [47, 48]). Dang et al. [30] also used CAPEX as a measure of investment policy. Although not hypothesized there results also suggest significant relationship between size and investment policy.

The fourth hypothesis of the study was that firm size has a significant impact on diversification. This hypothesis has also been supported by the results of the study. Size of a firm increases by increase in operations. Increase in operations comes from increase in number of business segments a firm operates in. Thus, rationally a larger firm should be operating in more segments than a smaller firm. Increase in number of segments reduces the risks associated with operating in a single segment. The risk is of low profitability, new entrants, high market volatility, etc. To reduce these risks, firms thus diversify theirselves either in a related way or in an unrelated way; either by merging with other firms or by acquiring other firms. The rationale of diversification by firms is present in the previously mentioned phrase of Markowitz, i.e. "Don't put all your eggs in one basket". Although the statement of Markowitz was related to the portfolios, it is applicable in this context too. This diversification and moving into other segments (product segments or geographical segments) require financing. Large firms have large pools of financing available which makes it easier for large firms to diversify than small firms. Small firms than mostly use concentration strategy and put all of their resources in one segment they are operating in. No study exclusively has studied this relationship in past. However, Wilcox et al. [50] study on mergers and acquisition showed that diversification is related to size of a firm.

The fifth hypothesis of the study was that firm size has a significant impact on firm performance. Using ROA and ROE as measures of performance study found support for the relationship between size and performance. Dang et al. [30] also found support for such a relation using ROA and Tobin $Q$ as measures of performance. Agyei and Marfo-Yiadom [52] also reported the same result. Larger firms have large revenues; large revenues are a source of more profits. More profit means more return to investors and thus a high performance. Thus, large firms have high financial performance than small firms.

The sixth hypothesis of the study was that firm size has a significant impact on compensation and incentives. Using pay level as proxy of compensation, study has found some support towards hypothesis. Study used pay level as a dummy variable because of less availability of data and set criteria for giving 0 or 1 to any firm which already has been explained in methodology. Despite of the fewer disclosures by the firms, the study has found support. This is because larger firms must make more disclosures as they have to comply more with the regulations, plus disclosures and compliance with regulations build trust among investors and give a positive signal to the market. Larger firms thus may report their level of salaries given to the staff of the firm.

The seventh hypothesis of the study was that firm size has a significant impact on board structure. Results of the study support this hypothesis. We used both NEDs and independent directors to study board structure. Using only NEDs, Dang et al. [30] also found support for such result. (They did not hypothesize it though.) With increase in size of firm, governance compliance becomes more important and regulatory authorities impose more strict regulations. Thus, large firms appoint more NEDs and independent directors. In particular after 2008 and corporate governance scandals, firms are now paying more attention towards the independence of board. Further, the presence of independent and non-executive directors is felt good by investors as these directors typically protect rights of shareholders, especially minority shareholders. Thus, again to give a positive signal to the market, large firms have more an independent board than small firms.

Last hypothesis of the study was that different measures of firm size have different sensitivities regarding different practices of corporate finance. The hypothesis has been fully supported. This was the main objective of the study. As previously mentioned, this result is important and shows that different proxies have different explanatory powers towards different areas. Necessary care thus is required while selecting firm size proxy for studying any specific area.

\section{Conclusion}

The aim of the study was to examine impact of different measures of firm size on seven important areas of corporate finance which are financial policy, dividend policy, investment policy, diversification, firm performance, compensation and incentives and board structure (corporate governance). Besides examining this impact of proxies on major practices of corporate finance, another major objective of the study was to check the sensitivity of different proxies of firm size on these practices of corporate finance. Data of five countries, i.e. Brazil, Russia, India, China and South Africa, were analysed. Overall results supported the hypotheses. Study concludes that different proxies of firm size are differently related to practices of corporate finance based on sign, significance 
and $R^{2}$. All proxies capture different aspects of firm size and have different implications for corporate finance. Thus, this study confirms "measurement effect" in "size effect". Unfortunately, this means that many of past studies are not robust and are biased. Researchers thus need to be careful when selecting any proxy of firm size for their research keeping in mind the scope and context of their work. Choosing a proxy thus is a theoretical and empirical question.

Our study provides important guidelines for researchers, managers and investors at large. Firstly, study showed that different proxies yield different results for a same area. Care and attention thus must be paid while selecting proxy of firm size in relation to the variable it is being studied for. Results of the study otherwise may become biased and do not reflect the actual reality. It is better to check that which proxy is suitable in the context before using it. Secondly, investors should pay special attention while making investment decision. Large firms do have large payment of dividend and are more diversified. Investors choosing small firms to invest for should do some work (cost and benefit analysis) before investing. Thirdly, managers of large firms should keep on diversifying, paying off dividends to give a good signal to market as to distinguish themselves from poor performing firms. Managers while making internal decisions like decisions to take on new project or decision to change capital mix should also use proper proxy of firm size.

Every study has its own merits and demerits. Similarly, this study also has some limitations. Some of these limitations are: (1) data availability was the major limitation of the study. We did not have access to any database of data because of which the study had to rely on available resources and included data from independent websites. Chance of error in such a data may be high. Future researchers may try to access data from reliable databases. (2) The study used data only for 10 years. Future researchers may use data over a larger period of time like 25 years. (3) The study used data only from five countries and from only 25 companies of each country. Future researchers may use more cross sections, more countries with more number of companies. (4) The study used only four proxies of firm size which were felt most important. There are other proxies available too which were not studied. Researchers in future may use any other proxies of firm size. A comprehensive study of all possible firm size measures may be conducted. (5) Study used only seven major practices of corporate finance. There can be many other practices as corporate finance is a vast field. Researchers in future may study the sensitivity of firm size measures on any other practices of corporate finance. (6) Study used sign, significance and $R^{2}$ sensitivity. There may be software or techniques for measuring sensitivity.
Future researchers may use them. (7) Study used dummy variable for dividend policy. Future studies may use dividend payout ratio to measure dividend policy.

\section{Abbreviations}

BRICS: Brazil, Russia, India, China and South Africa; CAPEX: Capital expenditure; FL: Financial leverage; MVE: Market value of equity; OLS: Ordinary least square; RBV: Resource-based view; ROA: Return on assets; ROE: Return on equity.

\section{Acknowledgements}

Not applicable.

\section{Authors contributions}

This paper is from Masters' dissertation of author SDH. Authors SG and ZG are supervisors of author SDH. SDH conceptualized, designed and drafted the study, ZG provided data for the study, and SG finalized the manuscript. IN helped in review stage and addressed the reviewers' comments. All authors read and approved the final manuscript.

\section{Funding}

No funding has been availed for the study.

\section{Availability of data and materials}

Data from open sources like annual reports of companies was extracted. Data used in the study can be provided/ uploaded by the corresponding author where required. List of companies can also be provided. The data has not been used from any data stream as they were not accessible to the authors. All data is available in annual reports of the companies used in the study and on websites like Morningstar.com.

\section{Competing interests}

Authors declare that there are no competing interests.

\section{Author details \\ ${ }^{1}$ Faculty of Management Sciences, Riphah International University, Rawal- pindi, Islamabad, Pakistan. ${ }^{2}$ Department of Management Sciences, COMSATS University, Wah Campus, Wah Cantonment, Pakistan.}

Received: 6 August 2019 Accepted: 26 February 2020

Published: 16 April 2020

\section{References}

1. Coase RH (1937) The nature of the firm. Economica 4(16):386-405

2. Pervan M, Višić J (2012) Influence of firm size on its business success. Croat Oper Res Rev 3(1):213-223

3. You JI (1995) Small firms in economic theory. Camb J Econ 19(3):441-462

4. Agarwal NC (1981) Determinants of executive compensation. Ind Relat J Econ Soc 20(1):36-45

5. Geiger SW, Cashen LH (2007) Organizational size and CEO compensation: the moderating effect of diversification in downscoping organizations. J Manag Issues 19(2):233-252

6. Lambert RA, Larcker DF, Weigelt K (1993) The structure of organizational incentives. Adm Sci Q 38(3):438-461

7. Damanpour F (1992) Organizational size and innovation. Organ Stud 13(3):375-402

8. Forés B, Camisón C (2016) Does incremental and radical innovation performance depend on different types of knowledge accumulation capabilities and organizational size? J Bus Res 69(2):831-848

9. Laforet S (2013) Organizational innovation outcomes in SMEs: effects of age, size, and sector. J World Bus 48(4):490-502

10. Lee G, Xia W (2006) Organizational size and IT innovation adoption: a meta-analysis. Inf Manag 43(8):975-985

11. Moch MK, Morse EV (1977) Size, centralization and organizational adoption of innovations. Am Sociol Rev 42(5):716-725

12. Haveman HA (1993) Organizational size and change: diversification in the savings and loan industry after deregulation. Adm Sci Q 38(1):20-50 
13. Anderson TR, Warkov S (1961) Organizational size and functional complexity: a study of administration in hospitals. Am Sociol Rev 26(1):23-28

14. Barber AE, Wesson MJ, Roberson QM, Taylor MS (1999) A tale of two job markets: organizational size and its effects on hiring practices and job search behavior. Person Psychol 52(4):841-868

15. Markham SE, McKee GH (1991) Declining organizational size and increasing unemployment rates: predicting employee absenteeism from withinand between-plant perspectives. Acad Manag J 34(4):952-965

16. Gordon G, Becker S (1964) Organizational size and managerial succession: a re-examination. Am J Sociol 70(2):215-222

17. Bellizzi JA (1981) Organizational size and buying influences. Ind Mark Manag 10(1):17-21

18. Carroll GR, Mayer KU (1986) Job-shift patterns in the Federal Republic of Germany: the effects of social class, industrial sector, and organizational size. Am Sociol Rev 51(3):323-341

19. Schminke M (2001) Considering the business in business ethics: an exploratory study of the influence of organizational size and structure on individual ethical predispositions. J Bus Ethics 30(4):375-390

20. Wickert C, Scherer AG, Spence $\sqcup$ (2013) Implementing and communicating corporate social responsibility: implications of firm size and organizational cost. University of Zurich, Institute of Business Administration, UZH business working paper (339)

21. Wickert C, Scherer AG, Spence $\sqcup J$ (2016) Walking and talking corporate social responsibility: implications of firm size and organizational cost. J Manag Stud 53(7):1169-1196

22. Frank MZ, Goyal VK (2003) Testing the pecking order theory of capital structure. J Financ Econ 67(2):217-248

23. Kurshev A, Strebulaev IA (2007) Firm size and capital structure. In: AFA 2008 New Orleans meetings paper

24. Ebel Ezeoha A (2008) Firm size and corporate financial-leverage choice in a developing economy: evidence from Nigeria. J Risk Finance 9(4):351-364

25. Baker KH, Saadi S, Dutta S, Gandhi D (2007) The perception of dividends by Canadian managers: new survey evidence. Int J Manag Finance 3(1):70-91

26. Eriotis N (2011) The effect of distributed earnings and size of the firm to its dividend policy: some Greek data. Int Bus Econ Res J (IBER) 4(1):67-74

27. Uwuigbe U, Jafaru J, Ajayi A (2012) Dividend policy and firm performance: a study of listed firms in Nigeria. Account Manag Inf Syst 11(3):442

28. Rajan R, Zingales $L$ (1995) What do we know about capital structure? Some evidence from international data. J Finance 50:1421-1460

29. Moeller SB, Schlingemann FP, Stulz RM (2004) Firm size and the gains from acquisitions. J Financ Econ 73(2):201-228

30. Dang C, Li ZF, Yang C (2018) Measuring firm size in empirical corporate finance. J Bank Finance 86:159-176

31. Hashmi SD, Gulzar S, Khan MJ, Akhtar M (2018) Sensitivity of firm size measures to practices of corporate finance: evidence from Sharı'ah compliant firms. J Islam Bus Manag 8(2):538-558

32. Coleman S, Cohn R (1999) Small firm use of leverage: a comparison of men and women-owned firms. In: Conference proceedings, United States Association for small business and entrepreneurship, San Diego, January, pp 14-17

33. Chatterjee S, Eyigungor B (2019) The firm size and leverage relationship and its implications for entry and concentration in a low interest rate world. Working paper

34. Harris M, Raviv A (1991) The theory of capital structure. J Finance 46(1):297-355

35. Kurshev A, Strebulaev IA (2015) Firm size and capital structure. Q J Finance 5(03):155-188

36. Schwartz E, Van Tassel RC (1950) Some suggested changes in the corporate tax structure. J Finance 5(4):410-420

37. Titman S, Wessels R (1988) The determinants of capital structure choice. J Finance 43(1):1-19

38. Cooley TF, Quadrini V (2001) Financial markets and firm dynamics. Am Econ Rev 91(5):1286-1310

39. Nor FM, Ariffi B (2006) Pyramidal ownership structure, capital structure and investment policy: a case of Malaysian listed firms. Unpublished dissertation, Universiti Kebangsaan Malaysia, Selangor, Malaysia

40. Jensen MC, Meckling WH (1976) Theory of the firm: managerial behavior, agency costs and ownership structure. J Financ Econ 3(4):305-360

41. Madura J (2011) International financial management. Cengage Learning, Boston
42. Maladjian C, Khoury RE (2014) Determinants of the dividend policy: an empirical study on the Lebanese listed banks. Int J Econ Finance 6(4):240-256

43. Mui YT, Mustapha M (2016) Determinants of dividend payout ratio: evidence from Malaysian public listed firms. J Appl Environ Biol Sci 6:48-54

44. Raza SA, Karim MZA (2016) Do liquidity and financial leverage constrain the impact of firm size and dividend payouts on share price in emerging economy. J Finance Econ Res 1(2):73-88

45. Daunfeldt SO, Hartwig F (2014) What determines the use of capital budgeting methods? Evidence from Swedish listed companies. J Finance Econ 2(4):101-112

46. Graham JR, Harvey CR (2001) The theory and practice of corporate finance: evidence from the field. J Financ Econ 60(2):187-243

47. Hartwig F (2012) Four papers on top management's capital budgeting and accounting choices in practice

48. Galagan P (1997) Strategic planning is back. Train Dev 51(4):32-37

49. Purkayastha S, Manolova TS, Edelman LF (2012) Diversification and performance in developed and emerging market contexts: a review of the literature. Int J Manag Rev 14(1):18-38

50. Wilcox HD, Chang KC, Grover V (2001) Valuation of mergers and acquisitions in the telecommunications industry: a study on diversification and firm size. Inf Manag 38(7):459-471

51. Deshpande R, Farley JU, Webster FE Jr (1993) Corporate culture, customer orientation, and innovativeness in Japanese firms: a quadrad analysis. J Mark 57(1):23-37

52. Agyei SK, Marfo-Yiadom E (2011) Dividend policy and bank performance in Ghana. Int J Econ Finance 3(4):202

53. Bolarinwa ST, Obembe OB (2019) Firm size-profitability nexus: an empirical evidence from Nigerian listed financial firms. Glob Bus Rev 20(5):1109-1121

54. Beatty RP, Zajac EJ (1990) Top management incentives, monitoring, and risk-bearing: a study of executive compensation, ownership, and board structure in initial public offerings. In: Academy of management proceedings, vol 1990, no 1. Academy of Management, pp 7-11

55. Graham JR, Li S, Qiu J (2012) Managerial attributes and executive compensation. Rev Financ Stud 25(1):144-186

56. Barney J (1991) Firm resources and sustained competitive advantage. J Manag 17(1):99-120

57. Gabaix X, Landier A (2008) Why has CEO pay increased so much? Q J Econ 123:49-100

58. Litch A (2002) Accountability and corporate governance. www.ssrn.com. Accessed Sept 2016

59. Daily CM, Dalton DR, Cannella AA (2003) Corporate governance: decades of dialogue and data. Acad Manag Rev 28(3):371-382

60. Fama EF, Jensen MC (1983) Separation of ownership and control. J Law Econ 26(2):301-325

61. Pradhan RP, Dasgupta P, Bele S (2013) Finance, development and economic growth in BRICS: a panel data analysis. J Quant Econ 11(1\&2):308-322

62. Hammoudeh S, Sari R, Uzunkaya M, Liu T (2012) The dynamics of BRICS's country risk ratings and domestic stock markets, U.S. stock market and oil price. Math Comput Simul (in press)

63. Mehran H (1995) Executive compensation structure, ownership, and firm performance. J Financ Econ 38:163-184

64. Linck JS, Netter JM, Yang T (2008) The determinants of board structure. J Financ Econ 87:308-328

65. Frank MZ, Goyal VK (2009) Capital structure decisions: which factors are reliably important? Finan Manag 38(1):1-37

66. Coles J, Daniel N, Naveen L (2006) Managerial incentives and risk-taking. J Financ Econ 79:431-468

67. Ezeoha AE (2008) The impact of major firm characteristics in the financial leverage of Quoted Companies in Nigeria. Ph.D Thesis, Department of Banking and Finance University of Nigeria Enugu Campus

68. Ross S (1977) The determination of financial structure: the incentive signaling approach. Bell J Econ 8:23-40

\section{Publisher's Note}

Springer Nature remains neutral with regard to jurisdictional claims in published maps and institutional affiliations. 